\title{
Deficitul de vitamină D la populația infantilă între 0 lună şi 24 de luni
}

\author{
Nicolae Grigore', Adrian Haşegan' ${ }^{1}$, Maria Totan', Camelia Grigore ${ }^{3}$ \\ ${ }^{1}$ Departamentul de Urologie, Facultatea de Medicină, Universitatea „Lucian Blaga“, Sibiu, România \\ ${ }^{2}$ Facultatea de Medicină, Universitatea „Lucian Blaga“, Sibiu, România \\ ${ }^{3}$ Laboratorul de Analize Medicale, Spitalul de Pediatrie, Sibiu, România
}

\begin{abstract}
REZUMAT
Introducere. Vitamina D are un rol bine cunoscut în absorbția calciului şi menținerea unui sistem osos sănătos. Deficitul de Vitamina D duce la apariția rahitismului. 25-hidroxi-Vitamina D reprezintă cel mai important metabolit al vitaminei $D$ şi concentrația plasmatică a acesteia reflectă cel mai bine cantitatea de vitamină $D$ la om. Scopul acestui studiu a fost de a analiza nivelul de 25-(OH) D la copiii între 1 lună şi 24 de luni, internați în Spitalul de Pediatrie din Sibiu, cu diverse patologii, pentru a analiza care este situația deficitului de Vitamina D la această populație şi, totodată, de a folosi aceste valori pentru a impulsiona prevenția rahitismului la această categorie de vârstă .

Material și metodă. Am efectuat un studiu retrospectiv pe un lot de 200 copii, cu vârste cuprinse între 1 lună şi 24 de luni, internați în diferite secții ale Spitalului Clinic de Pediatrie Sibiu în perioada 01.09.2015 - 01.11.2016, la care s-a dozat nivelul plasmatic de 25- $(\mathrm{OH}) \mathrm{D}$. Am considerat că nivelul optim de $25-(\mathrm{OH}) \mathrm{D}$ este valoarea peste $30 \mathrm{ng} / \mathrm{ml}$, insuficiența de Vitamina D a fost definită ca valori ale 25-(OH) D cuprinse între 20 şi $29 \mathrm{ng} / \mathrm{ml}$, iar deficitul de vitamină $D$ a fost definit ca valori ale $25-(\mathrm{OH}) \mathrm{D}$ sub $20 \mathrm{ng} / \mathrm{ml}$.

Rezultate. Din totalul de 200 pacienți, 111 copii $(55,5 \%)$ cu vârste cuprinse între o lună şi 24 de luni au prezentat nivele plasmatice ale 25-(OH) D sub $30 \mathrm{ng} / \mathrm{ml}$, cu o valoare medie de 28,68 ng/ml. Din cei 111 pacienți cu nivele ale $25-(\mathrm{OH}) \mathrm{D}$ sub $30 \mathrm{ng} / \mathrm{ml}, 87$ de pacienți (78\%) au prezentat valori ale 25-(OH) D cuprinse între 20 şi $29 \mathrm{ng} / \mathrm{ml}$, cu o valoare medie de 22,61 ng/ml şi doar 24 de copii (22\%) au avut valori sub $20 \mathrm{ng} / \mathrm{ml}$, cu o valoare medie de $17,2 \mathrm{ng} / \mathrm{ml}$.

Concluzii. Peste jumătate dintre copiii cu vârste cuprinse între o lună şi 24 de luni prezintă valori plasmatice scăzute ale 25-(OH) D. Acest fapt sugerează că există un număr important de copii în arealul nostru geografic care au nivele suboptimale de vitamină $D$, ceea ce ar trebui să ridice o problemă pentru familiile lor, pentru profesioniştii din domeniul medical, cât şi pentru autoritățile din sănătate. Pe lângă valoarea epidemiologică, determinarea nivelelor de 25-(OH) D reprezintă o analiză de laborator importantă pentru copiii cu vârste cuprinse între o lună şi 24 de luni, ce poate fi folosită ca punct de pornire în tratamentul de prevenție a rahitismului, care trebuie instituit la această vârstă.
\end{abstract}

Cuvinte cheie: deficit vitamină $D, 25$-hidroxivitamină $D$, rahitism

\section{INTRODUCERE}

Istoric. Vitamina D este bine cunoscută pentru rolul său în absorbţia şi menţinerea calciului în oase, iar deficiența acesteia are ca rezultat rahitismul. Rahitismul este o boală care apare la sugari şi copiii mici care au o expunere inadecvată la lumina solară şi care prezintă asociat şi un aport dietetic scăzut de Vitamina D. Rahitismul nu mai este considerat o boală a trecutului sau o boală a țărilor cu venituri mici (1). În ultimii ani, există multe explicații cu privire la deficitul de Vitamina D şi la relația sa cu stilul de viață modern: expunerea mai re- dusă la lumina solară, „statul în casă“, opțiunile dietetice (2).

Pentru a preveni rahitismul la sugari, în multe țări se aplică strategii de suplimentare cu Vitamina $\mathrm{D}$, dar dozele utilizate nu se bazează pe măsuratori ştiinţifice, deoarece dozarea vitaminei D a fost posibilă tehnic doar în ultimii ani. 25-hidroxiVitamina D serică (25-(OH)D) este cel mai important metabolit al vitaminei $\mathrm{D}$ şi concentraţia acesteia în ser reflectă cel mai fidel nivelul de vitamină D în organism.

Nivelul optim de Vitamina D a fost definit pe baza efectului acestei vitamine asupra sănătății 
osoase.(3). Există multe dezbateri despre ce înseamnă deficitul de Vitamina D. Institutul de Medicină şi Academia Americană de Pediatrie definesc deficitul de Vitamina D ca nivelul de 25- $(\mathrm{OH}) \mathrm{D}$ mai mic de $20 \mathrm{ng} / \mathrm{ml}$, insuficiența Vitaminei D nivelul de $25-(\mathrm{OH})$ D între 20 şi $29 \mathrm{ng} / \mathrm{ml}$ şi nivelul optim de Vitamina D atunci când 25-(OH) D depăşeşte $30 \mathrm{ng} / \mathrm{ml}$ (4).

Reprezintă deficitul de Vitamina D o problemă în România? Nu se cunosc date referitoare la nivelul de Vitamina D la populația din România, deoarece determinarea Vitaminei D nu este un test de laborator obişnuit, fiind costisitor şi nefiind rambursat de Casa Națională de Asigurări de Sănătate.

La nivel mondial însă, deficitul de Vitamina D pare să fie o reală problemă de sănătate publică, deoarece studiile din Statele Unite au arătat că $25 \%$ până la 57\% dintre adulții şi adolescenții americani au deficit de Vitamina D. De asemenea, studii făcute în India, Liban, Arabia Saudită, Turcia şi Emiratele Arabe Unite au arătat că 30-50\% dintre adulții şi copiii din aceste țări au defícit de Vitamina D (5). În studiul nostru am dorit să comparăm valorile de 25-(OH) D ale copiilor cu vârste cuprinse între o lună şi 24 de luni, internați în Spitalul de Pediatrie din Sibiu, cu diferite patologii, cu datele din literatură şi, analizând nivelul de 25-hidroxivitamină D al acestora, să oferim un suport ştiințific pentru modularea tratamentului rahitismului la aceşti copii.

\section{MATERIAL ŞI METODĂ}

Am efectuat un stud iu retrospectiv pe 200 de copii, cu vârste cuprinse între o lună şi 24 de luni, internați în Secțiile Spitalului de Pediatrie din Sibiu, în perioada 01.09.2015 - 01.11.2016, şi am analizat rezultatele nivelurilor de 25-(OH) D. Pentru studiu am folosit rezultatele arhivei electronice a spitalului.

Nivelurile serului 25-(OH) D au fost măsurate printr-un test imunoenzimatic de tip ELFA automatizat, folosind un analizor Vidas PC al firmei BioMerieux, Franța, utilizând reactivi Biomerieux, în laboratorul central al Spitalului de Pediatrie Sibiu, România. Acest test utilizează un principiu de testare competitivă utilizând proteina de legare recombinantă a Vitaminei $\mathrm{D}$, care permite măsurarea atât a $25(\mathrm{OH}) \mathrm{D} 2$, cât şi a $25(\mathrm{OH}) \mathrm{D} 3$.

Probele de sânge au fost centrifugate cu promptitudine şi serurile au fost stocate la frigider la -20 grade Celsius până la analizare. Probele stocate au fost apoi trimise la laborator pentru măsurarea serului $25-(\mathrm{OH}) \mathrm{D}$.
Am considerat ca nivel optim de $25-(\mathrm{OH}) \mathrm{D}$ valorile $\geq 30 \mathrm{ng} / \mathrm{ml}$, Vitamina D insuficientă cu nivelurile de $20-29 \mathrm{ng} / \mathrm{ml}$ şi deficitul de Vitamina D cu niveluri $<20 \mathrm{ng} / \mathrm{ml}$.

\section{ANALIZA STATISTICĂ}

Toate analizele de date au fost efectuate utilizând versiunea 15.0 a programului statistic SPSS pentru Windows (SPSS, Chicago, IL, SUA). Am clasificat nivelele de ser $25-(\mathrm{OH}) \mathrm{D}$ în trei categorii distincte: $>30 \mathrm{ng} / \mathrm{mL}$, între 20 şi $30 \mathrm{ng} / \mathrm{mL}$ şi $<20$ $\mathrm{ng} / \mathrm{mL}$.

\section{REZULTATE}

Dintre cei 200 de copii testaţi, cu vârste cuprinse între o lună şi 24 de luni, 111 copii $(55,5 \%)$ au avut concentrații de 25-(OH) Vitamina D sub $30 \mathrm{ng} / \mathrm{ml}$, media de grup de 28,68 ng/ml (SD 4.2) (Fig. 1).

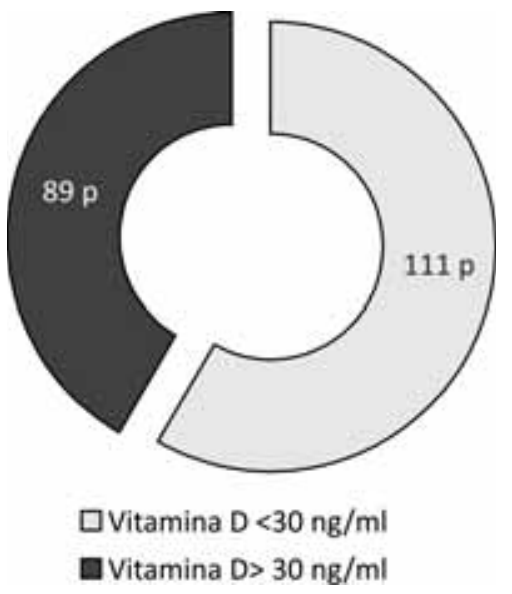

FIGURA 1. Concentrația plasmatică a vitaminei $D$

Între aceşti 111 pacienţi, 87 de pacienţi (78\%) au avut valori 25-(OH) D între 20 şi 29 ng/ml, media de grup de 22,61 ng/ml (SD 4,1) şi doar $24 \mathrm{de}$ pacienți $(22 \%)$ au avut valori sub $20 \mathrm{ng} / \mathrm{ml}$, cu media de grup de 17,2 ng/ml (SD 4.1) (Fig. 2).

\section{DISCUTุII}

Vitamina D este vitamina dependentă de expunerea la soare. În timpul expunerii la lumina soarelui, 7-dehidrocolesterolul din piele absoarbe radiațiile UV şi este transformat în preVitamina D3. PreVitamina D3 se izomerizează în Vitamina D3. Previtaminul D3 şi Vitamina D3 absorb, de asemenea, radiațiile UV şi sunt transformate într-o varietate de produse foto cu proprietăți biologice diferite. Sinteza Vitaminei D este dependentă de soare şi, prin urmare, este influențată foarte mult de sezon, 


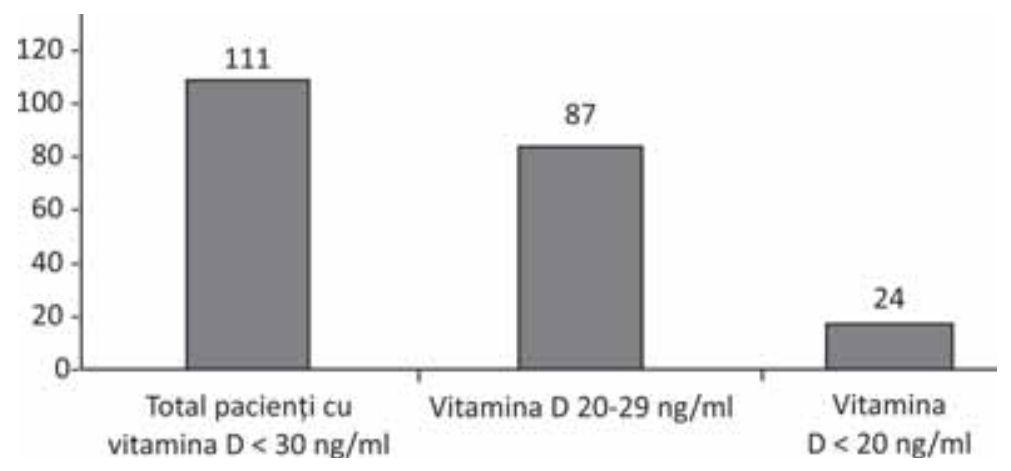

FIGURA 2. Vitamina D - distribuție redusă a nivelurilor timp al zilei, latitudine, altitudine, poluarea aerului, pigmentarea pielii, utilizarea de creme de protecție solară, trecerea prin sticlă şi plastic şi îmbătrânirea. După producere, Vitamina D este metabolizată în ficat şi rinichi în 25-hidroxi-Vitamina $\mathrm{D}$, care este forma sub care circulă Vitamina $\mathrm{D}$, şi 1,25-dihidroxiVitamina $\mathrm{D}$, care este forma biologic activă. 1,25-dihidroxi-Vitamina D joacă un rol important în reglarea metabolismului calciului şi fosfatului pentru menținerea funcțiilor metabolice şi pentru sănătatea scheletului. Majoritatea celulelor şi organelor din organism au un receptor de Vitamina D şi multe celule şi organe sunt capabile să producă 1,25-dihidroxi Vitamina D. Ca rezultat, 1,25-dihidroxiVitamina D influențează un număr mare de căi metabolice, fapt care explică rolul Vitaminei D în bolile autoimune, unele tipuri de cancer, bolile cardiovasculare, bolile infecțioase, diabetul de tip 2, schizofrenia (6).

În ultimii ani, cu ajutorul tehnicilor de laborator imunologice, putem măsura nivelul de Vitamina D în ser. În urma măsurătorilor, multe țări au raportat o prevalență ridicată a nivelurilor scăzute de Vitamina D, cunoscută sub numele de deficit de Vitamina D (niveluri de 25-OHD $<20 \mathrm{ng} / \mathrm{ml}$ ) sau insuficienţa Vitaminei D (niveluri între 20 şi $29 \mathrm{ng} / \mathrm{ml}$ ).

Principalele motive pentru nivelul scăzut al Vitaminei D sunt (7):

- Lipsa Vitaminei D în dietă asociată de multe ori cu expunerea inadecvată la soare;

- Incapacitatea de a absorbi Vitamina D din intestin;

- Incapacitatea de a procesa Vitamina D din cauza afecțiunilor renale sau hepatice.

Sugarii şi copiii sunt expuşi riscului scăderii nivelului de Vitamina D, deoarece laptele matern conţine un nivel scăzut de Vitamina D şi majoritatea formulelor pentru sugari nu conțin Vitamina D în cantitate adecvată (8).

De asemenea, există multe surse care sfătuiesc părinții să nu expună sugarii şi copiii la soare, ceea ce reduce sinteza Vitaminei D din piele (9).
Anumite boli, diagnosticate în această perioadă a vieții, afectează capacitatea organismului de a absorbi cantități adecvate de Vitamina D prin tractul intestinal. Exemple: boala celiacă, boala Crohn şi fibroza chistică (10).

Persoanele cu afecţiuni renale şi hepatice cronice prezintă un risc crescut de scădere a nivelului activ al Vitaminei D (11). Există şi cauze mai puțin frecvente ale deficitului de Vitamină D (bolile enzimatice familiale).

Primul rol descris al Vitaminei D a fost acela în absorbția şi menținerea calciului în oasele sănătoase, iar prima boală asociată cu deficiența de Vitamina D a fost rahitismul (12). Anul 1645 este recunoscut ca fiind anul în care în literatura ştiințifică a început să se vorbească despre rahitism, deoarece David Whistler (1619-1684) a descris boala în teza sa de doctorat la Universitatea din Leiden, Olanda, cu titlul „De morbo puerile anglorum, quem Patrio idiomate indigenae vocant Rickets" (În ceea ce priveşte boala copiilor englezi, care în limba engleză se numeşte „Rickets“).

Mulți ani, boala a fost diagnosticată utilizând doar parametri clinici şi radiologici, deoarece nu a existat o metodă analitică pentru determinarea nivelului de Vitamina D. În prezent, cel mai bun indicator al nivelului de Vitamina D este 25-(OH) D serică.

Deşi nu există un consens universal acceptat pentru a defini nivelul optim al Vitaminei D, deficitul de Vitamina D este definit de majoritatea experților ca fiind valoarea $25 \mathrm{OHD}<20 \mathrm{ng} / \mathrm{ml}$ şi insuficiență de Vitamină D ca fiind valoarea $25 \mathrm{OHD}<30$ $\mathrm{ng} / \mathrm{ml}$. Aceste valori au fost stabilite luând in considerare o sănătate optimă a oaselor (13).

În studiul actual, aceste limite au fost aplicate copiilor cu vârste între 1 lună şi 24 de luni şi în urma analizei rezultatelor am găsit un număr mare de copii, 111 de pacienți $(55,5 \%)$ cu niveluri insuficiente de Vitamina D (Vitamina $\mathrm{D}<30 \mathrm{ng} / \mathrm{ml}$ ) şi doar 24 de copii (22\%) cu niveluri deficitare de Vitamina D (niveluri $<20 \mathrm{ng} / \mathrm{ml}$ ). 
Am comparat rezultatele studiului nostru cu un studiu asiatic în care insuficiența Vitaminei D (definită ca ser $25-(\mathrm{OH}) \mathrm{D}<30 \mathrm{ng} / \mathrm{ml})$ a fost găsită la 90,3\% dintre copiii testați şi deficiența de Vitamina D (definită ca $25-(\mathrm{OH}) \mathrm{D}$ seric $<20 \mathrm{ng} / \mathrm{ml})$, care a fost găsită în 51,0\% (14). Analizând aceste cifre, putem concluziona că există o mare varietate a deficitului de Vitamina D în întreaga lume.

Studiul nostru are unele limitări: determinarea 25OHD a fost făcută în toamnă, prevalența deficienței putând fi mai mică, deoarece determinarea a fost după sezonul de vară, când nivelurile de Vitamina D cresc, în urma expunerii la soare. Trebuie să continuăm cercetarea în primăvară, după sezonul de iarnă, perioadă în care expunerea la soare este mai redusă în aria noastră geografică.

Acest studiu are o latură pozitivă: este o primă cercetare asupra nivelurilor de Vitamina D la copiii din zona noastră, internați în clinică, şi ne oferă o idee de pornire despre deficitul de Vitamina D la populația infantilă la care se începe suplimentarea cu Vitamina D pentru prevenirea rahitismului.

\section{CONCLUZII}

Nivelurile serice scăzute de $25-(\mathrm{OH}) \mathrm{D}$ afectează mai mult de jumătate dintre sugarii şi copiii între 1 lună şi 24 de luni internați, sugerând că în regiunea noastră există mulți copii care pot avea niveluri suboptimale de Vitamina D. Acest fapt trebuie sa fie cunoscut de către familiile copiilor, pentru a preveni rahitismul la această vârstă, precum şi de către profesioniştii din domeniul medical şi autoritățile de sănătate publică care fac politicile de prevenție a rahitismului. Determinarea 25- $(\mathrm{OH})$ Vitamina $\mathrm{D}$ este un test important pentru copiii între 1 lună şi 24 de luni pentru o prevenție eficientă a rahitismului la această vârstă. 